\title{
СТРАТЕГІЯ СТВОРЕННЯ ТА ОЦІНЮВАННЯ ФУНКЦІОНУВАННЯ СИСТЕМ УПРАВЛІННЯ ЯКІСТЮ МЕДИЧНОЇ ОСВІТИ. ДРУГЕ ПОВІДОМЛЕННЯ. ТРАНСФОРМАЦІЯ ІДЕЙ УПРАВЛІННЯ ЯКІСТЮ НА ОСНОВІ ПРИНЦИПУ «ДУАЛЬНИХ СИСТЕМ»
}

\author{
О. П. Мінцер, О. К. Толстанов, Г. В. Загорій \\ Національна медична академія післядипломної освіти імені П. Л. Шупика
}

\begin{abstract}
Пропонується методологія оцінювання функціонування систем управління якістю медичної освіти. Для системи оцінювання якості післядипломної медичної освіти застосовано принцип дуального управління.

Розглядається також можливість використання квадрупольної моделі. Модель складається з чотирьох кластерів, що містять по чотири критерії оцінювання систем управління якістю медичної освіти та відповідні показники для аналізу цих критеріїв.
\end{abstract}

Ключові слова: системи управління якістю в післядипломній медичній освіті, дуальні системи, критерії систем управління якістю.

\section{СТРАТЕГИЯ СОЗДАНИЯ И ОЦЕНКИ ФУНКЦИОНИРОВАНИЯ СИСТЕМ УПРАВЛЕНИЯ КАЧЕСТВОМ МЕДИЦИНСКОГО ОБРАЗОВАНИЯ. ВТОРОЕ СООБЩЕНИЕ. ТРАНСФОРМАЦИЯ ИДЕЙ УПРАВЛЕНИЯ КАЧЕСТВОМ НА ОСНОВЕ ПРИНЦИПА «ДУАЛЬНЫХ СИСТЕМ»}

\author{
О. П. Минцер, А. К. Толстанов, Г. В. Загорий \\ Национальная медицинская академия последипломного образования имени П. Л. Шупика
}

\begin{abstract}
Предлагается методология оценки функционирования систем управления качеством медицинского образования. Для системы оценки качества последипломного медицинского образования применен принцип дуального управления. Основная идея подхода заключается в замене многомерной дифференцированной модели объекта оценки на двухуровневую модель, которая в определенной мере способна гармонизировать существующую систему критериев, показателей, характеристик, а также способствовать усилению направленности оценочной деятельности на обеспечение и улучшение качества. Двухуровневая система оценки качества образования, по сути, отражает классическую дуальную систему: на первом ее уровне (управляемая система) остаются критерии, показатели и характеристики (например, системно организованные на основе критерия целесообразности). На втором, более высоком уровне (управляющая система), используются комплексные модели, критерии и показатели работы менеджмента в системе управления качеством высшего образования.

Рассматривается также возможность использования квадрупольной модели. Модель состоит из четырех кластеров, содержащих по четыре критерия оценки систем управления качеством медицинского образования и соответствующие показатели для анализа этих критериев. Кластеры представляют и интегральную оценку систем управления качеством медицинского образования, технологическую составляющую (процессно-ориентированную), а также отдельные дополнительные критерии. Дана характеристика кластеров и показателей.
\end{abstract}

Ключевые слова: системы управления качеством в последипломном медицинском образовании, дуальные системы, критерии систем управления качеством.

\section{STRATEGY AND EVALUATION OF THE OPERATION OF QUALITY MANAGEMENT SYSTEMS OF MEDICAL EDUCATION. THE SECOND MESSAGE. TRANSFORMATION OF IDEAS OF QUALITY MANAGEMENT BASED ON THE PRINCIPLE OF «DUAL SYSTEM»

\author{
O. P. Mintser, O. K. Tolstanov, H. V. Zahoriy \\ P. L. Shupyk National Medical Academy of Postgraduate Education
}

\begin{abstract}
It was proposed an assessment methodology functioning of the quality management systems of medical education. For quality evaluation system of postgraduate medical education the principle of dual control was appllied.
\end{abstract}

(C) О. П. Мінцер, О. К. Толстанов, Г. В. Загорій 


\section{МЕДИЧНА ІНФОРМАТИКА TA IHЖЕНЕРІЯ}

It was also considered the possibility of using of quadrupole model. The model consists of four clusters, each containing four quality management systems of medical education evaluation criteria and relevant indicators for the analysis of these criteria.

Key words: quality management system in postgraduate medical education, dual system, criteria for quality management systems.

Вступ. Можна погодитися з думкою, що сьогодні не існує жодної освітньої системи у світі, яка могла б запропонувати якість освіти, котра задовольнить світове співтовариство. Загальною проблемою $є$ незадоволеність якістю вищої освіти державних органів управління освітою, а також широких кіл громадськості, роботодавців.

Усе це, природно, стимулює пошук ефективніших підходів до управління якістю освіти, узгоджених із міжнародними тенденціями, міжнародними показниками та критеріями якості вищої освіти. При цьому підкреслюється, що важливо створити систему управління якістю освіти, адекватну реальним умовам і таку, що забезпечує орієнтацію на якісні критерії в діяльності вищих навчальних закладів (ВН3). Насамперед йдеться про кінцеві результати цієї діяльності - необхідний рівень підготовки кадрів.

Сьогодні актуалізуються питання формування систем забезпечення якості вищої освіти, орієнтованих на міжнародні стандарти серії ISO, TQM та інші $[1,2,4,5]$, спрямовані, так чи інакше, на поліпшення якісних аспектів діяльності освітніх систем та установ. Необхідний перехід від існуючих сьогодні лінійних підходів до оцінювання діяльності ВНЗ із позицій якості до більш комплексного та системного рівня. Сформована в останнє десятиліття система оцінювання характеризується рядом слабких сторін, таких як «розмита» орієнтація на кінцеві результати діяльності навчальних закладів. Моделі оцінювання, що використовуються, спираються на безліч диференційованих характеристик і параметрів діяльно сті ВНЗ, що не ранжовані за їхньою значимістю 3 погляду переважної спрямованості на якість вищої освіти; а їхня кількість не збалансована з ресурсами оцінювальної діяльності (тимчасовими, професійнокваліфікаційними, фінансовими тощо). В результаті процедура оцінювання стає вельми трудомісткою та витратною при невисокій їі ефективності. У діючій системі недостатньо скоординовані технології зовнішнього оцінювання та самооцінювання. Вони часто дублюють одна одну, замість того, щоб бути взаємно комплементарними.

Поширеною $є$ думка, що якість підготовки фахівців вищими навчальними закладами можна пов'язати з широким застосуванням стандартів у системі управління, насамперед - стандарту ISO 9001. На сьогодні тисячі організацій у всьому світі мають сертифікати, які підтверджують, що їхні системи управління відповідають вимогам цього стандарту. 3'явилось навіть правило, згідно з яким «серйозна» організація повинна мати подібний сертифікат.

Насправді у багатьох випадках системи управління якістю (СУЯ) суттєво не впливають на якість продукції та послуг і на результативність діяльності організацій у цілому. Згідно з оцінками багатьох спеціалістів, реально працюють (з певними обмовками!) лише близько 30 \% сертифікованих СУЯ [3]. В інших випадках їх створення зводиться до написання великої кількості документів, які дуже слабко використовуються в діяльності організацій.

Аналізуючи подібне становище в роботі [3] висунута ідея щодо його ключової причини, а саме: СУЯ існують паралельно $з$ реальними системами управління, в яких керівники організацій приймають дієві управлінські рішення. СУЯ може бути дійсно гарно задокументована, структурована згідно зі стандартом ISO 9001, відповідні документи створюються в рамках внутрішніх і зовнішніх аудитів, але ними не користуються керівники організації для прийняття та реалізації найважливіших рішень. По суті, створюється «нежива» система. Проте, «жива» система, в рамках якої приймаються рішення, може бути неструктурованою та погано задокументованою, побудованою більшою мірою на звичках і уявленнях керівників.

Отже, надзвичайно актуальною та важливою проблемою є створення та обгрунтування принципів вірної інтерпретації та ефективного застосування СУЯ.

Вкрай важливим стає врахування особливостей дуального управління, коли апріорна інформація стосовно об'єкта чи керованої системи не є достатньою, а постійний моніторинг може надати додаткові відомості щодо властивостей такого управління.

Мета роботи: запропонувати метрику визначення якості управління якістю навчання в післядипломній медичній освіті. 
Результати та їх обговорення. В якості базової термінології в роботі використана низка понять, серед яких ключовим було «якість освіти». Саме воно, по суті, є джерелом плутанини навіть на національному рівні.

Будемо розуміти під якістю вищої освіти збалансовану відповідність системи передавання знань потребам суспільства, його цілям, вимогам, нормам, стандартам. Відповідно, якістю підготовки фахівців із вищою освітою є збалансована відповідність підготовки особистості потребам суспільства та країни, їх цілям, вимогам, нормам, стандартам. У свою чергу, ключовими словами в цьому визначенні є терміни «збалансованість» і «відповідність». Зрозуміло, домогтися повної відповідності численних показників, що характеризують систему передавання знань або підготовку конкретного фахівця, практично неможливо. Саме для цього передбачається категорія збалансованості, що повинна визначити остаточну суму позитивних i негативних характеристик процесу передавання знань або формування випускника.

Для системи оцінювання якості післядипломної медичної освіти нами застосовано принципи дуального управління, характерною рисою якого, як підкреслював ще К. Шеннон, є тісний взаємозв'язок між минулим та майбутнім. Важливим питанням також є вирішення проблеми адекватності прийнятих рішень, іншими словами, їхньої повноти та всебічності. Недостатність апріорної інформації призводить до необхідності поєднувати в певному сенсі вивчення системи, якою ми управляємо, та як такого управління нею. Неможливо оптимально управляти системою, не знаючи її характеристик, але можливо вивчати об'єкт, керуючи ним, і тим самим мати можливість покращувати управління, прагнучи до оптимального. Отже, управляючі дії мають двоїстий характер. Вони служать як засобом вивчення, пізнання об'єкта, так і засобом спрямування його до бажаного (тобто оптимального) стану. Саме таке управління, при якому управляючі дії мають двоїстий характер, й прийнято називати дуальним управлінням [9].

Основна ідея підходу полягає в заміні багатопараметричної диференційованої моделі об'єкта оцінювання на дворівневу модель, що до певної міри здатна гармонізувати існуючу систему критеріїв, показників і характеристик, сприяти посиленню спрямованості оціночної діяльності на забезпечення та поліпшення якості. Дворівнева система оцінювання якості освіти, по суті, відо- бражає класичну дуальну систему: на першому іiі рівні (керована система) залишаються критерії, показники та характеристики (наприклад, системно організовані на основі критерію доцільності). На другому, більш високому рівні (керуюча система), використовуються комплексні моделі, критерії та показники роботи менеджменту в системі управління якістю вищої освіти.

Використання принципів дуального управління (запропонованого А. А. Фельдбаум на основі теорії статистичних рішень) для оцінювання якості підготовки фахівців у післядипломній освіті може виявитися успішним у тих випадках, коли задана апріорна щільність розподілу зовнішніх впливів і параметрів керованої системи освіти, а показником якості є середній ризик. На жаль, такий шлях вирішення часто виявляється настільки складним, що його можна використовувати тільки в порівняно простих випадках. Оскільки недостатні обсяги апріорної інформації відносяться також і до щільності розподілу, то є сенс шукати інші шляхи вирішення завдань дуального управління, що не потребують знання апріорних щільностей розподілів.

Одна 3 таких можливостей пов'язана із застосуванням принципів трансформування об'єкта оцінювання. Його зміст полягає в переході від сукупності об'єктів оцінювання до єдиного об'єкта у вигляді системи якості освіти (системи управління якістю). Подібний перехід до системи управління якістю як об'єкта оцінювання дає можливість мінімізувати число всіх компонентів i аспектів діяльності вищого навчального закладу в їхній загальній орієнтації на забезпечення та безперервне вдосконалення цієї якості. Крім того, забезпечується перехід від сукупності розрізнених критеріїв якості 3 окремих аспектів діяльності до загального критерію якості діяльності ВНЗ із «підпорядкуванням» усій їхній сукупності загальному критерію. Зрозуміло, успішне управління можливе, якщо властивості керованої системи добре відомі та керуюча система швидко реагує на змінення керованої системи. На з'ясування цих властивостей, тобто ідентифікацію керованої системи, потрібен певний час. Навряд чи можна очікувати, що занадто поспішне управління без достатньої інформації про властивості керованої системи, з одного боку, і дуже обережне управління, хоча й засноване на накопиченій інформації, але чинне, коли потреба в ньому минула, - з іншого боку, можуть привести до успішного результату. Аналогічний зважений 
підхід є необхідним і відносно визначення необхідних витрат на управління, швидкості оповіщення фахівців про прийняті рішення.

В результаті для побудови фундаменту метрики застосували раніше використаний нами квадрупольний принцип [11]. В якості критеріїв для керуючої системи пропонуємо використовувати наступні чотири - оперативність управління - L, що розуміємо як «середній час для прийняття коригуючого рішення»; питома вага фінансових витрат на функціонування керуючої системи в загальному кошторисі - F; адекватність коригувальних рішень, що розуміємо як середнє число рішень із досліджуваної проблеми - А та, нарешті, відкритість управління - V, що визначається як середня кількість фахівців, які беруть участь у вирішенні конкретної проблеми, не ознайомлених своєчасно (по заданому тимчасовому критерію) 3 прийнятими рішеннями.

Для оцінювання якості роботи керованої системи в рамках тієї ж квадрупольної системи, згідно 3 міжнародними та вітчизняними рекомендаціями [8, 10], ми пропонуємо такі критерії. Перший «виконання планових показників із підготовки фахівців» - Р. Наступні характеристики стосуються показників задоволеності: закладів охорони здоров'я компетенцією випускників системи післядипломної освіти (ПО) - Z , слухачів системи ПО якістю навчання - $\mathrm{Z}_{\mathrm{s}}$, а також кількості помилок, зроблених слухачами після навчання за певний проміжок часу B.

Зрозуміло, система детального та цільового дослідження якості підготовки фахівців багаторівнева. В їі основі зазвичай використовуються акредитаційні показники. На жаль, вони часто дублюють один одного, замість того, щоб бути взаємно комлементарними. Тим не менш, для кожної системи (керуючої та керованої) обгрунтовуються.

Одним із принципів, закладених у сучасних системах якості, є процесно-орієнтований підхід [12], відповідно до якого бажаний результат досягається ефективніше, якщо діяльність з управління якістю за видами діяльності розглядається не як сукупність деяких робіт, а як етапний процес. Застосування в організації системи процесів, разом із їх визначенням та взаємодіями, а також управління «процесним підходом» віддзеркалюється на третій та четвертій площинах. Критеріями, що фіксуються, є швидкість зміни критеріїв на першій та другій площинах, їх прискорення, нестійкість динаміки, наявність загрозливої динаміки.

Щоб зв'язати всі площини оцінювання в єдину систему запропоноване використання квадрупольного принципу обчислення [12]. Загальний вигляд інтегрального правила для прийняття рішень наведено на рисунку 1.

\section{IV рівень «процесно-орієнтований підхід»}

\section{III рівень «процесно-орієнтований підхід»}

II рівень «керуєма система»

\section{І рівень «керуюча система»}

Підкреслимо також, що важливим принципом управління якістю $є$ безперервна реєстрація результатів технологічного процесу, особливо на стику між окремими системними процесами.
Нарешті, при формуванні системи якості освіти слід враховувати й інші рекомендації стандарту ISO 9001 [2]. Зокрема, система якості трактується як система, що складається 3 трьох підсистем: 
управління якістю, забезпечення якості та підтвердження якості; для самооцінювання діяльності ВНЗ прийнято за основу модель, що спирається на принципи загального управління якістю, дуальності управління, комплексної автоматизації тощо.

\section{Література}

1. Системи управління якістю. Основні положення та словник термінів (ISO 9000:2005, IDT) : ДСТУ ISO 9000:2007. - [Чинний від 2008-01-01]. - К. : Держспоживстандарт України, 2008. - 29 с. - (Національний стандарт України).

2. Системи управління якістю. Вимоги (ISO 9001:2008, IDT) : ДСТУ ISO 9001:2009. - [Чинний від 2009-09-01]. - К. : Держспоживстандарт України, 2009. - 26 с. - (Національний стандарт України).

3. Стратегія створення та оцінювання функціонування систем управління якістю медичної освіти. Перше повідомлення. Постановка проблеми / О. П. Мінцер, О. К. Толстанов, Г. В. Загорій, Т. П. Калита // Медична інформатика та інженерія. - 2015. - № 2. - С. 14-26.

4. World Federation for Medical Education. The Edinburgh Declaration. History of the First Forty Years, 1972 -2012/ H. Karle. - 30 с. - Режим доступу: http://wfme.org/documents/about-wfme/79-wfme-history-of-the-first-fortyyears-1972-2012/file.

5. Международные стандарты ВФМО по улучшению качества в медицинском образовании. Европейская спецификация. Рабочая группа по обеспечению качества. Копенгаген : Всемирная организация здравоохранения, 2007. - 82 с.

6. Федорков Е. Д. Управление в медицинских и социальных системах на основе моделирования и оптимизации дуальных динамических процессов : автореф. дис. на соискание наук, степени докт. техн. наук : спец. 05.13.10 «Управление в социальных и экономических системах»/ Е. Д. Федорков. - М., 1999. - 42 с.
Висновки. 1. Обгрунтовано використання дуальної системи управління якістю в системі післядипломної медичної освіти.

2. Запропоновано критерії для оцінювання функціонування керуючої та керованої систем. Вони створюють квадрупольний фундамент системи перехресної взаємної корекції.

7. Федорков Е. Д. Математическое описание динамики медицинских объектов как систем массового обслуживания / Е. Д. Федорков // Оптимизация и моделирование в автоматизированных системах : межвуз. сб. науч. тр. - Воронеж : ВГТУ 1997. - С. 193-198.

8. Последипломное медицинское образование. Международные стандарты ВФМО улучшения качества. - Копенгаген : Всемирная организация здравоохранения, 2003. - 22 с.

9. Cooke-Davies T. The maturity of project management in different industries / Cooke-Davies T., Arzymanow A. // International Journal of Project Management. - 2003. № 21 (6). - Р. 471-478.

10. Корнєєва Л. Якість освітніх послуг з позицій міжнародних стандартів серії ISO 9000:2000/ Л. Корнєєва, М. Сіницький // Освіта і управління. 2006. - Т. 9, № 1. - С. 87-90.

11. Мінцер О. П. Концептуальні підходи до систематизації методів оцінки якості медичної допомоги / О. П. Мінцер, Т. П. Іванова // Медична інформатика та інженерія. - 2010. - № 3. - С. 4-16.

12. Іванова Т. П. Обгрунтування управління системою оцінки якості надання медичної допомоги дітям в умовах багатопрофільної лікарні : автореф. дис. на здобуття наук. ступеня канд. мед. наук : спец. 14.03.11 «Медична та біологічна інформатика і кібернетика» / Т. П. Іванова. - K., 2010. - 19 c. 